\title{
Establishment of a quenching probe method for detection of NPM1 mutations in acute myeloid leukemia cells
}

\author{
NORIKO KAWAGUCHI-IHARA ${ }^{1,2}$, MAI ITOH ${ }^{1}$, IKUO MUROHASHI ${ }^{2}$ and SHUJI TOHDA ${ }^{1}$ \\ ${ }^{1}$ Department of Laboratory Medicine, Tokyo Medical and Dental University, Bunkyo-ku, Tokyo 113-8519; \\ ${ }^{2}$ Department of Health Sciences, Saitama Prefectural University, Koshigaya, Saitama 343-8540, Japan
}

Received December 24, 2014; Accepted January 26, 2016

DOI: $10.3892 / \mathrm{ol} .2016 .4225$

\begin{abstract}
Nucleophosmin (NPM1) mutations, generally consisting of a four base-pair insertion, are present in $\sim 60 \%$ of all cytogenetically normal acute myeloid leukemia (AML) cases. The mutation is clinically significant as an important prognostic factor. Direct sequencing is the current standard method of mutation detection, however, it is quite costly and time consuming. The present study aimed to establish a highly sensitive quenching probe (QP) method to detect NPM1 mutations efficiently. Melting curve analysis was performed using a QP, following polymerase chain reaction for amplification of the involved region of the gene. The curve derived from the fluorescent intensity with respect to the temperature of OCI/AML3, a heterozygous NPM1 mutant AML cell line, was $\mathrm{W}$-shaped with melting peaks at $61^{\circ} \mathrm{C}$ and $68^{\circ} \mathrm{C}$. That of $\mathrm{M}-07 \mathrm{e}$, the homozygous wild type cell line, was $\mathrm{V}$-shaped with a melting peak at $68^{\circ} \mathrm{C}$. Thus, the curve derived from the mutant allele was easily discriminated from that of the wild-type allele. The mutant allele was detected in concentrations as low as $3 \%$ as determined by a subsequent sensitivity study. With a short testing time and a high sensitivity, this assay was applicable for NPM1-mutated AML patient samples and is appropriate for screening NPM1 mutations. It does require further examination as to whether it would be useful as a detection method for other mutant alleles since NPMI mutations may consist of 61 known types of mutant sequences. To the best of our knowledge, this is the first report describing the QP method for the detection of NPM1 mutations.
\end{abstract}

\section{Introduction}

Mutations found in the nucleophosmin gene (NPM1) are novel molecular abnormalities identified in acute myeloid leukemia

Correspondence to: Dr Shuji Tohda, Department of Laboratory Medicine, Tokyo Medical and Dental University, Yushima 1-5-45, Bunkyo-ku, Tokyo 113-8519, Japan

E-mail: tohda.mlab@tmd.ac.jp

Key words: acute myeloid leukemia, melting curve analysis, NPM1, $\mathrm{PCR}$, quenching probe
(AML). NPM1 mutations are present in $\sim 60 \%$ of cytogenetically normal AML cases, and they are an important prognostic factor $(1,2)$. Therefore, AML with mutated NPM1 has been defined as a provisional entity in the 4th edition of the World Health Organization classification (3). The mutations typically appear as a 4 base pair (bp) insertion at position 956 through 971 in exon 12, resulting in frame-shift mutations (1). To date, 61 known types of mutations have been reported $(2,4-7)$. The most common NPM1 mutation is an insertion of TCTG at position 956-959, referred to as type A (see Table I), and it is detected in $~ 80 \%$ of NPM1 mutation cases $(1,8,9)$.

Direct sequencing is the current standard method for detecting NPM1 mutations. Unfortunately, this method is costly and time consuming. In addition, the sensitivity of this method is low, with the lower limit of detection beginning at $\sim 20 \%$ (10). Therefore, polymerase chain reaction (PCR) methods such as electrophoresis (11), melting curve analysis (12), high-resolution melting (HRM) analysis which detects the different melting temperatures of the PCR products (13), locked nucleic acid clamp-mediated PCR $(10,14)$, and capillary electrophoresis $(15,16)$ have been investigated as potentially more sensitive methods for detection of this $4 \mathrm{bp}$ mutation.

Recently, the quenching probe (QP) method has been developed as a novel technique for mutation detection $(17,18)$. A QP is an oligonucleotide with a fluorescent dye-modified cytosine at the $5^{\prime}$ or $3^{\prime}$ end. After PCR amplification of the sequences including the mutation site, a melting curve analysis using QPs is performed. At low temperature, QPs hybridize with PCR products, and their fluorescence is quenched by an electron transfer to adjacent guanine bases in the PCR products. With an increase in temperature, the QPs dissociate from the products, causing an increased fluorescent signal emission (19). Because QPs dissociate from unmatched products at lower temperatures than perfectly matched products, it is possible to detect mutant alleles (20). In the present study, the sensitivity and effectiveness of a newly established QP method was examined.

\section{Materials and methods}

Cells and DNA extraction. Two leukemia cell lines were used: an AML cell line, OCI/AML3, with a heterozygous type A NPM1 mutation (9) and a megakaryoblastic leukemia cell 
line, M-07e, with homozygous wild-type NPM1. DNA was extracted from the cells by the SepaGene agglutination partition method (EIDIA, Tokyo, Japan). To examine the sensitivity of the detection method, mixed samples of OCI/AML3 DNA and $\mathrm{M}-07 \mathrm{e}$ DNA in various ratios were used. Blood samples were obtained from $5 \mathrm{AML}$ patients prior to treatment, with their informed consent. The DNA extracted from these samples was also examined. The study was approved by the Ethics Review Board in Tokyo Medical and Dental University (Tokyo, Japan).

QP method. The QP method from a previously reported protocol (18) was performed using a LightCycler $\mathrm{Nano}^{\mathrm{TM}}$ (Roche Diagnostics, Mannheim, Germany). The sequences of PCR primers and QPs are presented in Table I. A total of 3 QPs with different sequences were designed to compare efficiency. The PCR cycling conditions were as follows: A $95^{\circ} \mathrm{C}$ hold $(10 \mathrm{~min}) ; 10$ cycles at $95^{\circ} \mathrm{C}(10 \mathrm{sec}), 65-55^{\circ} \mathrm{C}$ ramp (10 sec, $\left.1^{\circ} \mathrm{C} / \mathrm{step}\right), 72^{\circ} \mathrm{C}(30 \mathrm{sec})$; followed by 45 cycles of $95^{\circ} \mathrm{C}$ (10 sec), $55^{\circ} \mathrm{C}(10 \mathrm{sec})$, and $72^{\circ} \mathrm{C}(30 \mathrm{sec})$. The reaction volume consisted of $19.5 \mu \mathrm{l}$ with $18 \mathrm{ng}$ DNA sample, $1.5 \mathrm{mM} \mathrm{MgCl}_{2}$, $0.2 \mu \mathrm{M}$ primers, $0.2 \mu \mathrm{M} \mathrm{QP}$, and $4 \mu 1$ reaction mix of LC 480 Genotyping Master (Roche Diagnostics). Upon completion of the PCR cycles, the temperature was maintained at $95^{\circ} \mathrm{C}$ for $1 \mathrm{~min}$, followed by $45^{\circ} \mathrm{C}$ for $1 \mathrm{~min}$, and then gradually increased to $95^{\circ} \mathrm{C}$ at a rate of $0.2^{\circ} \mathrm{C} / \mathrm{sec}$, during which the fluorescent signal was continually acquired. The curves derived from the fluorescent intensity with respect to temperature, -dFluorescence/dTemperature (-dF/dT), were obtained using LightCycler Nano ${ }^{\mathrm{TM}}$ software version 1.0 (Roche Diagnostics). Each assay was performed in duplicate to verify the reproducibility of the method.

Direct sequencing. For confirmation of sequences, the PCR products were treated with Amicon Ultra Centrifugal Filter Units (Sigma-Aldrich, St. Louis, MO, USA) to remove the primers and dNTPs, and then sequenced using a 3130xl Genetic Analyzer and BigDye terminator Reaction kit v3.1 (Applied Biosystems, Foster city, CA, USA) according to the manufacturer's protocol.

\section{Results}

Discrimination between wild-type and mutant alleles. The curves for $-\mathrm{dF} / \mathrm{dT}$ as determined by QP analysis using the three variations of QPs (QP 1, QP 2, and QP 3) are shown in Fig. 1. DNA from M-07e cells possessing the homozygous wild-type alleles presented with single concave-up curves, with the lowest point at about $65-68^{\circ} \mathrm{C}$. DNA from OCI/AML3 cells possessing the wild-type allele and the type A mutant allele presented two concave-up curves with lowest points at 65- $68^{\circ} \mathrm{C}$ and $55-61^{\circ} \mathrm{C}$, respectively. In comparing the melting profiles of the three variations of QPs investigated, QP 2 was the most discriminative probe; the wild-type allele and type $\mathrm{A}$ mutant allele presented curves with the lowest points at $68^{\circ} \mathrm{C}$ and $61^{\circ} \mathrm{C}$, respectively. Therefore, further $\mathrm{QP}$ analysis was performed using QP 2.

Assay sensitivity. In order to evaluate the sensitivity of the QP assay, the OCI/AML3 DNA and M-07e DNA were mixed at
Table I. Primers, probes, and sequences of the mutated region.

\begin{tabular}{ll}
\hline Variable & \multicolumn{1}{c}{ Sequence } \\
\hline $\begin{array}{l}\text { PCR primers } \\
\text { Forward }\end{array}$ & 5'-tgatgtctatgaagtgttgtggttcc-3' \\
Reverse & 5'-ctctgcattataaaaaggacagccag-3' \\
Quenching probes & acttcctccactgccagagatc-(BODIPY FL) \\
1 & (BODIPY FL)-cctccactgccagagatcttgaa-P \\
2 & (BODIPY FL)-ctattcaagatctctggcagt-P \\
3 & \\
Sequences & caggctattcaagatctctggcagtggagg \\
Wild-type & caggctattcaagatctctgtctggcagtggagg \\
Type A mutant & \\
\hline
\end{tabular}

BODIPY FL is a green fluorescent dye. P, phosphorylation.

various ratios. Fig. 2 shows the representative results of the lower detection limit obtained using these mixed samples containing OCI/AML3 DNA and M-07e DNA. Recognizable curves with the $61^{\circ} \mathrm{C}$ melt point were obtained from samples containing as low as $6.25 \%$ OCI/AML3 DNA, or $3.125 \%$ of mutant allele.

Detection of NPM1 mutations in patients' samples. Out of the five patient samples examined, three samples presented the $\mathrm{W}$-shaped curves with lowest points at $61^{\circ} \mathrm{C}$ and $68^{\circ} \mathrm{C}$, indicating that these samples contained both the mutant alleles and the wild-type alleles. Fig. 3 shows the curves of sample 1 and sample 2, both containing wild-type and mutant alleles. The curve of sample 3 was similar to that of sample 1 (data not shown). Direct sequencing further confirmed that these three samples have a type A mutant allele (data not shown). The remaining two samples presented $\mathrm{V}$-shaped curves with lowest points at $68^{\circ} \mathrm{C}$, indicating that these samples contained wild-type allele only.

\section{Discussion}

In the present study, a QP method was established to detect NPM1 mutations easily with high sensitivity. To the best of our knowledge, this is the first report to use the QP method to detect NPM1 mutations. The curve derived from the mutant allele was easily discriminated from that of the wild-type allele. Thus far, the authors of the present study performed screening for NPMI mutations by gel electrophoresis of PCR products to detect a band 4-bp longer than the wild-type band; however, it was not clearly discriminative (data not shown). HRM analysis of the PCR products to detect the difference of the melting curves (13) was additionally performed by the present authors, but again, it was not clearly discriminative (data not shown). Compared with these two analyses, the QP method was superior in its specificity.

In terms of efficiency, the QP method took just 2 hours to perform. The sensitivity was quite high as the lower limit of detection was as low as a $3 \%$ concentration of mutant allele. In clinical settings, NPM1 assays are predominantly used for diagnosis at presentation, rather than for detection of minimal 

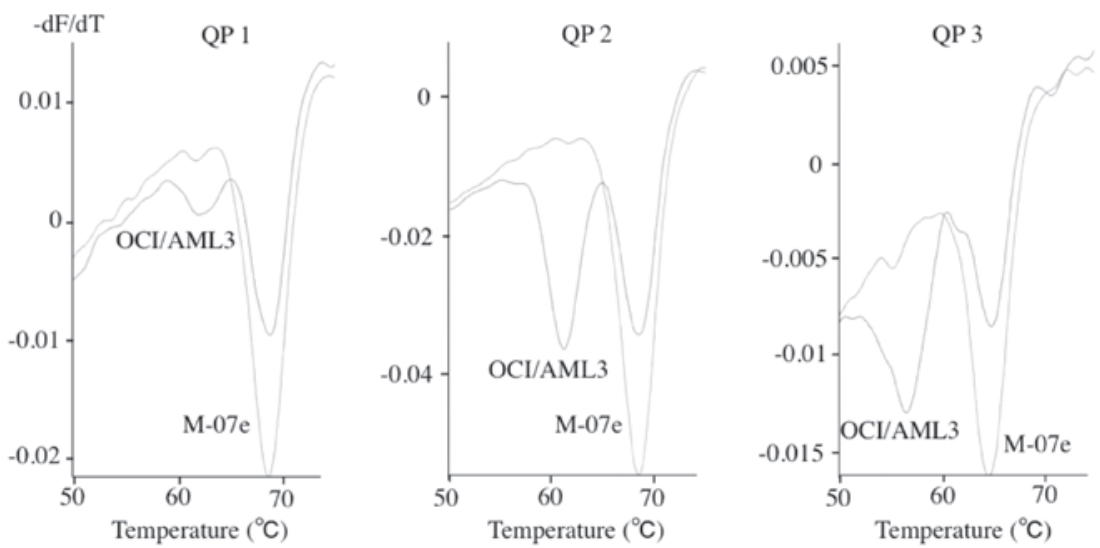

Figure 1. Comparison of derivative melting curves using three kinds of quenching probes (QP). -dF/dT indicates -d (Fluorescence)/d (Temperature).

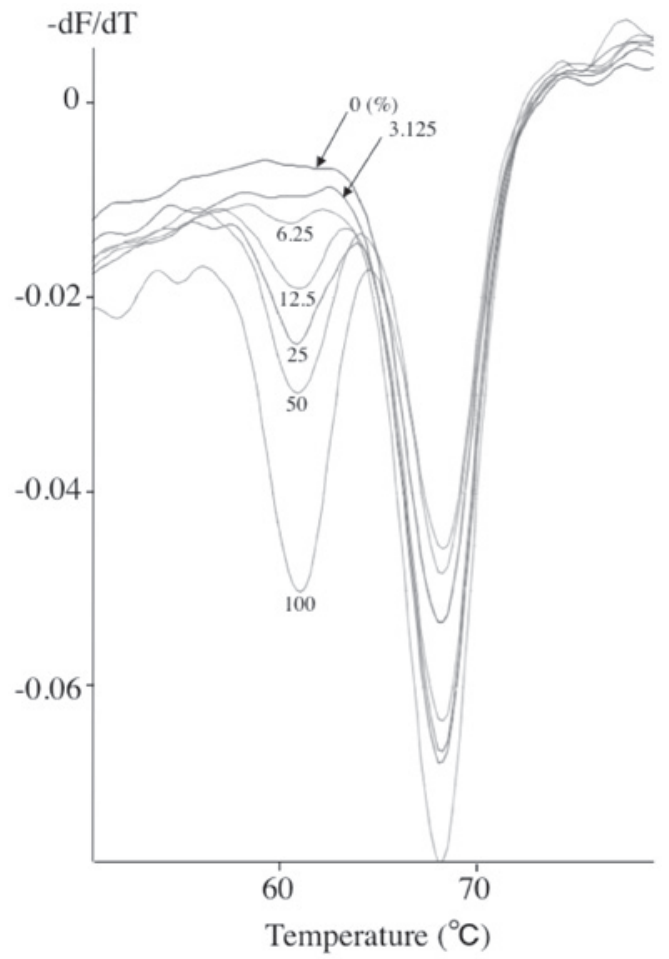

Figure 2. Sensitivity of quenching probes analysis for the detection of NPMI mutations. Numbers shown indicate the percentage of OCI/AML3 DNA.

residual diseases. The mutant alleles are typically present in at least $10 \%$ of the cells in AML blood or bone marrow samples, even in heterozygous mutant cases. Therefore, higher sensitivity is not necessarily needed for diagnosis. Moreover, by comparing the depth of the two curves as shown in Fig. 2, the approximate ratio between mutant allele and wild-type allele can be estimated.

The QP assay also demonstrated its applicability for clinical use. In the AML patient samples, the mutant allele was detected in three samples, which were all confirmed to be type A mutant cases. Non-type A mutant AML samples were not encountered in this study as the number of available AML samples were few. To date, at least 61 types of mutant sequences of NPM1 gene have been reported $(2,4-7)$. The QP 2 sequence used in this assay covers the mutated region of 57 of these types. If additional samples are available in the future,

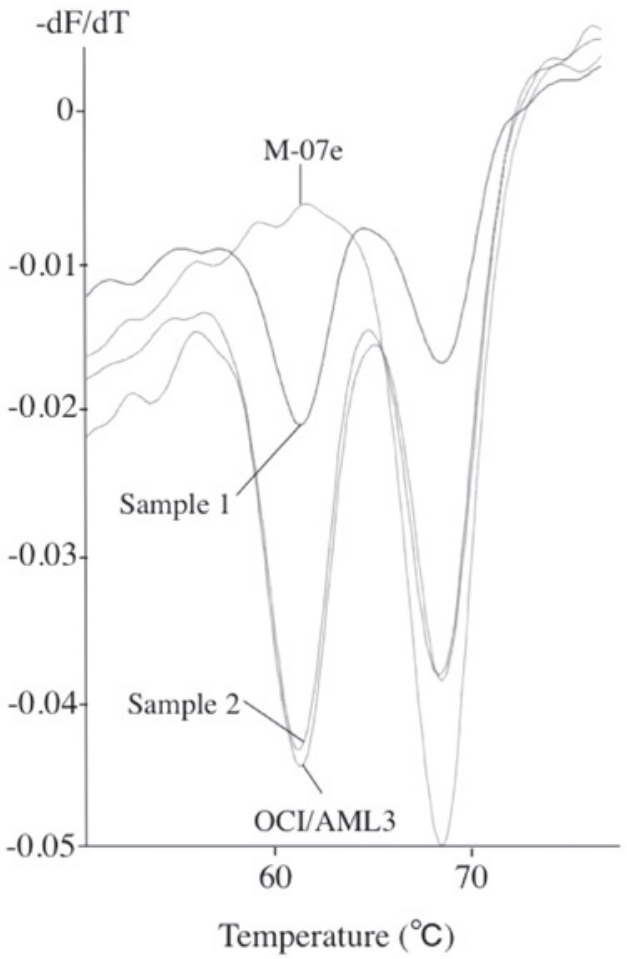

Figure 3. Derived melting curves from quenching probes analysis for the detection of NPM1 mutations in acute myeloid leukemia patient samples and cell lines.

further examination as to whether this method can detect these remaining mutant alleles should be performed. Based on the above findings, the QP method appears to be an effective tool for screening NPM1 mutations in AML cases.

\section{Acknowledgements}

This work was supported in part by a Grant-in-Aid for Scientific Research (C) from the Japan Society for the Promotion of Science (grant no. 18690522).

\section{References}

1. Falini B, Mecucci C, Tiacci E, Alcalay M, Rosati R, Pasqualucci L, La Starza R,Diverio D, Colombo E, Santucci A, et al: Cytoplasmic nucleophosmin in acute myelogenous leukemia with a normal karyotype. N Engl J Med 352: 254-266, 2005. 
2. Rau R and Brown P: Nucleophosmin (NPM1) mutations in adult and childhood acute myeloid leukaemia: Towards definition of a new leukaemia entity. Hematol Oncol 27: 171-181, 2009.

3. Arber DA, Vardiman JW, Brunning RD, Porwit A, Le Beau MM, Thiele J, Falni B, and Bloomfield CD: Acute myeloid leukaemia with recurrent genetic abnormalities. In: WHO classification of tumours of haematopoietic and lymphoid tissues. Swerdlow SH, Campo E, Harris NL, Jaffe ES, Pileri SA, Stein H, Thiele J and Vardiman JW (eds). Vol 2. 4th edition. IARC Press, Lyon, pp110-123, 2008

4. Pianta A, Fabbro D, Damiani D, Tiribelli M, Fanin R, Franzoni A Romanello M, Tell G, Di Loreto C and Damante G: Two novel NPM1 mutations in a therapy-responder AML patient. Hematol Oncol 28: 151-155, 2010.

5. Park SH, Chi HS, Shim H, Jang S and Park CJ: Two novel NPMI mutations in an acute myeloid leukemia patient transformed from primary myelofibrosis. Int J Lab Hematol 35: e1-e3, 2013.

6. Jeon Y, Seo SW, Park S, Park S, Kim SY, Ra EK, Park SS and Seong MW: Identification of two novel NPM1 mutations in patients with acute myeloid leukemia. Ann Lab Med 33: 60-64, 2013.

7. Ahmad F, Mandava S and Das BR: Mutations of NPM1 gene in de novo acute myeloid leukaemia: Determination of incidence, distribution pattern and identification of two novel mutations in Indian population. Hematol Oncol 27: 90-97, 2009.

8. Falini B, Nicoletti I, Martelli MF and Mecucci C: Acute myeloid leukemia carrying cytoplasmic/mutated nucleophosmin (NPMc+ AML): Biologic and clinical features. Blood 109: 874-885, 2007.

9. Quentmeier H, Martelli MP, Dirks WG, Bolli N, Liso A, Macleod RA, Nicoletti I, Mannucci R, Pucciarini A, Bigerna B, et al: Cell line OCI/AML3 bears exon-12 NPM gene mutation-A and cytoplasmic expression of nucleophosmin. Leukemia 19: 1760-1767, 2005.

10. Thiede C, Creutzig E, Illmer T, Schaich M, Heise V, Ehninger G and Landt O: Rapid and sensitive typing of NPM1 mutations using LNA-mediated PCR clamping. Leukemia 20: 1897-1899, 2006.

11. Oppliger Leibundgut E, Porret NA, Bienz Muggli M Baumgartner H, Dahlhaus $M$ and Baerlocher GM: Rapid and highly specific screening for NPM1 mutations in acute myeloid leukemia. Ann Hematol 92: 173-177, 2013.
12. Scholl S, Mügge LO, Landt O, Loncarevic IF, Kunert C, Clement JH and Höffken K: Rapid screening and sensitive detection of NPM1 (nucleophosmin) exon 12 mutations in acute myeloid leukaemia. Leuk Res 31: 1205-1211, 2007.

13. Tan AY, Westerman DA, Carney DA, Seymour JF, Juneja S and Dobrovic A: Detection of NPM1 exon 12 mutations and FLT3-internal tandem duplications by high resolution melting analysis in normal karyotype acute myeloid leukemia. J Hematol Oncol 1: 10, 2008.

14. Laughlin TS, Becker MW, Liesveld JL, Mulford DA, Abboud CN, Brown P and Rothberg PG: Rapid method for detection of mutations in the nucleophosmin gene in acute myeloid leukemia. J Mol Diagn 10: 338-345, 2008

15. Noguera NI, Ammatuna E, Zangrilli D, Lavorgna S, Divona M, Buccisano F, Amadori S, Mecucci C, Falini B and Lo-Coco F. Simultaneous detection of NPM1 and FLT3-ITD mutations by capillary electrophoresis in acute myeloid leukemia. Leukemia 19: 1479-1482, 2005.

16. Ottone T, Ammatuna E, Lavorgna S, Noguera NI, Buccisano F, Venditti A, Giannì L, Postorino M, Federici G, Amadori S and Lo-Coco F: An allele-specific RT-PCR assay to detect type A mutation of the nucleophosmin-1 gene in acute myeloid leukemia. J Mol Diagn 10: 212-216, 2008.

17. Tanaka R, Kuroda J, Stevenson W, Ashihara E, Ishikawa T, Taki T, Kobayashi Y, Kamitsuji Y, Kawata E, Takeuchi M, et al: Fully automated and super-rapid system for the detection of JAK2V617F mutation. Leuk Res 32: 1462-1467, 2008.

18. Ono A, Okuhashi Y, Takahashi Y, Itoh M, Nara N and Tohda S: Advantages of the quenching probe method over other PCR-based methods for detection of the JAK2 V617F mutation. Oncol Lett 4 205-208, 2012.

19. Kurata S, Kanagawa T, Yamada K, Torimura M, Yokomaku T, Kamagata $\mathrm{Y}$ and Kurane R: Fluorescent quenching-based quantitative detection of specific DNA/RNA using a BODIPY $((\mathrm{R}))$ FL-labeled probe or primer. Nucleic Acids Res 29: E34, 2001.

20. Rothberg PG, Ramirez-Montealegre D, Frazier SD and Pearce DA: Homogeneous polymerase chain reaction nucleobase quenching assay to detect the 1-kbp deletion in CLN3 that causes Batten disease. J Mol Diagn 6: 260-263, 2004. 